\title{
Open letter to Prime Minister Paul Martin: Broadband connectivity in Aboriginal communities
}

To the editor:

The following document is a copy of a letter that has been sent to Prime Minister Martin and the Federal Cabinet members by Geordi Kakepetum, Keewaytinook Okimakanak Executive Director.

The letter documents the need for Industry Canada programs to complete the work which has already begun in developing local broadband infrastructure solutions in Aboriginal communities across Canada. As well, the letter highlights the need for other federal government departments including Indian and Northern Affairs Canada, Health Canada, Heritage Canada, and Human Resource Development Canada to support the ongoing operation and development of applications that use these community networks.

The social and economic impact of these types of strategic investments support First Nations in developing health, education, business and governance opportunities for their membership.

Please forward this letter to other appropriate people who are working on addressing First Nation issues. Thank you in advance for your support.

Brian Beaton

K-Net / ON-RMO Coordinator

Keewaytinook Okimakanak

< brian.beaton@knet.ca $>$ 
Administration Office Fort Severn First Nation Ph: 1-807-478-1114 Fort Severn, Ontario

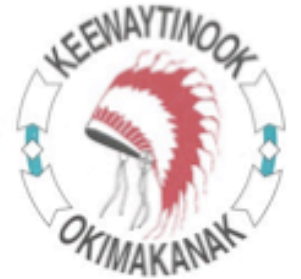

\section{Sub-Ottice}

115 King Str $\quad$ Ph: $\quad 1.807 .737 .1135$ P.O. Box 1439 Toll Free: 1-877-737-KNET Sioux Lookout, ON Fx: 1-807.737-1720 PQT 1B9 Website: http:liknet.ca

$P \cdot \nabla \cap{ }^{\prime} D P L b a '$

October 19,2004

The Right Honourable Paul Martin, MP, PC

Office of the Prime Minister

80 Wellington Street

Ottawa

K1A 0A2

Fax: 613-941-6900

Dear Prime Minister:

\section{RE: Broadband Connectivity in Aboriginal Communities}

At the Assembly of First Nations (AFN) gathering in Charlottetown this past summer the attached Chiefs' resolution (First Nation Telecommunication Technologies and Broadband Infrastructure) was tabled by Chief Raymond Mason from Keewaywin First Nation. The resolution recognizes the socio-economic importance of broadband connectivity in First Nations across the country. It directs the AFN leadership to ensure that Industry Canada (both regional and national programs) complete the job of ensuring that all Aboriginal communities have the opportunity to develop and maintain their own broadband infrastructure. The resolution also clarifies the role that other Federal government departments such as Indian and Northern Affairs Canada (INAC) and Health Canada need to undertake by supporting local and regional applications such as telehealth, e-learning, and e-commerce to ensure the ongoing sustainability of these community broadband networks.

Over the past twelve years, Industry Canada's Information Highways Application Branch (IHAB) along with regional economic development programs such as FedNor introduced a number of innovative programs (SchoolNet, CAP, Smart, Brand, etc) supporting communities across Canada in establishing a variety of local on-line services and initiatives. These programs and strategic investments are resulting in local social and economic development opportunities in rural and remote communities across the country. During this same development period, other departments supported a variety of local applications that utilized these different infrastructures that were being established in First Nations.

Deer Lake

McDowell Lake
Fort Severn

North Spirit Lake
Keewaywin

Poplar Hill 
Keewaywin First Nation is a good example of the type of socio-economic transformation that is able to take place as a result of these investments by Industry Canada. With no local telephone services in 1995, the community leaders supported the local school to get involved with the Community Access Program (CAP) and the First Nations SchoolNet (FNS) program that introduced computers and training support for technicians at the local school and CAP site. Then in 1998, the FNS program supported the use of a satellite service (MSAT and DirecPC) to establish a local internet connection. The regional economic development corporation (FedNor) then invested in a local community network connecting the band office, the health centre, the school and the police station to this internet connection. Local community members started running network cable between their homes so they could communicate over this single community internet connection at the school. Working with FedNor and other government departments, the Keewaywin leadership was able to raise enough capital (\$1.6 million) to get Bell Canada to put in telephone services throughout the community. This work was completed in December 2000. In January 2001, Keewaywin community members participated in their first video conference. In April 2001, Keewaywin joined the other First Nation members of Keewaytinook Okimakanak, to kick off Industry Canada's Aboriginal Smart Communities Demonstration project. Today, Keewaywin is operating their own local Applications Service Provider (ASP) with broadband connections to every building in their community over their own cable system that is delivering a variety of innovative services and applications including telehealth, e-leaming, e-commerce, etc.

It is important that any investment by the Federal government in the development of local broadband infrastructure, includes parallel investments in the ongoing development and operation of the different applications that address local needs. Strategic investments by INAC, Health Canada, Human Resource Development, Canadian Heritage supporting local broadband networks are required so they can remain sustainable. There are no federal or provincial programs that provide the necessary funds to maintain the operation of these services. This gap in funding must be addressed and eliminated.

There are various pilot projects that fund innovative services such as the Keewaytinook Okimakanak Telehealth Initiative or the Keewaytinook Internet High School. But these innovative projects are at risk unless operational funds are supported by the appropriate departments. Strategic capital investment from FedNor and other partners have made it possible to introduce local telemedicine, teleradiology, high school programs and other applications but now the need and challenge is to ensure the ongoing operation of these services.

The Auditor General noted in several reports about the challenges that First Nation communities are faced with as they try to work with the department of Indian and Northern Affairs Canada. Effective use of these new information communication technologies (ICTs) by INAC, Health Canada and First Nations will support the development of improved local services and opportunities. But these improvements will only occurred if these departments and their staff have the program dollars required to support the ongoing operation of these technologies and the broadband connections so the services can be sustained.

Today, federal regional agencies such as FedNor have the flexibility to compliment other programs such BRAND, that supports First Nations in completing the necessary local infrastructure builds. This type of program flexibility ensures that all communities, even those with limited financial and human 
resources are now able to compete for broadband infrastructure and develop local applications that address local needs. The National Satellite Initiative is supporting local regional economic opportunities through partnerships such as the Kativik Regional Government in northern Quebec with funding support from CED and their work with Keewaytinook Okimakanak in northern Ontario with strategic infrastructure investments by FedNor that now make satellite broadband available in nearly 30 remote Aboriginal communities in these inter-provincial regions.

First Nations want improved access to health care. Telehealth applications were included in the final Romanow report as one recommendation for delivering these services in the First Nations and rural and remote communities. Keewaytinook Okimakanak $(\mathrm{KO})$ and our partner First Nations are delivering an innovative telehealth service in remote First Nations across northwestern Ontario. First Nations require better academic results that are possible with proper investment and operation of e-learning resources that support local initiatives. The Keewaytinook Internet High School model is now being duplicated in First Nations in other provinces with our team's support. Better water and sewer treatment is possible with remote monitoring and training support that is now taking place in the KO Water Treatment Training initiative. Other applications including post secondary education, financial, band management, medical education, etc are all now happening at a distance in those First Nations that have the necessary broadband infrastructure required to support these applications.

There is still a great deal of work and investment required by everyone to ensure all Aboriginal communities are able to develop the necessary broadband infrastructure required to access and develop applications that address local needs and issues. Industry Canada has the necessary programs and personnel in place to ensure this work is completed if adequate funding is made available to complete the construction work. But beyond the infrastructure, First Nations require INAC, Health Canada and other federal government departments to be supporting the development and ongoing operation of innovative programs that are now possible using these new technologies. Your support is required to make this possible.

Keewaytinook Okimakanak and our member First Nations are proud of the work achieved through strategic investments by the Federal government and other partners. We are working with other First Nations, organizations and communities across Canada to support the development of local broadband infrastructure and applications. We would welcome you and any other official to visit our offices in Balmertown and any of our partner First Nations in Northwestern Ontario to learn more about these developments and to discuss opportunities to continue this important work. Please consider this letter as an open invitation to everyone to visit us in this special part of Canada.

Sincerely,

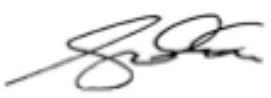

Geordi Kakepetum

Executive Director

Keewaytinook Okimakanak 
Cc: Federal cabinet members

PMO office

Auditor General

Grand Chief Phil Fontaine, Assembly of First Nations

Regional Chief Charles Fox, Chiefs of Ontario

Grand Chief Stan Beardy, Nishnawbe Aski Nation

Chiefs of Keewaytinook Okimakanak

Northern Federal Caucus

Louise Paquette, Director General, FedNor

Michael Binder, Assistant Deputy Minister, Industry Canada

The Honourable Roger Valley, MP, Kenora Riding 


\section{Assembly of First Nations Resolution Charlottetown, PEI, July, 2004}

SUBJECT: First Nation Telecommunication Technologies and Broadband Infrastructure MOVED BY: $\quad$ Chief Raymond Mason, Keewaywin First Nation, ON

WHEREAS the government of Canada has commited to connect every community to broadband services by 2005 ; and

WHEREAS broadband services and the resulting applications provide First Nations with the economic and social capacity to support new opportunities and developments locally, regionally, nationally and internationally; and

WHEREAS introducing broadband services and applications require an initial capital investment in each First Nation to establish the appropriate infrastructure and equipment that can carry high speed data as well as quality video and voice traffic; and

WHEREAS developing broadband applications for purposes such as the delivery of local education programs (e-learning), e-commerce and telehealth requires investments in new information and communication technologies (ICTs); and

WHEREAS Industry Canada has been supporting the introduction of these infrastructures and technologies over the past ten years through their regional economic development corporations as well as the Information Highway Applications Branch that administered such programs as the Community Access Program (CAP), First Nations SchoolNet (FNS), Smart Communities, Broadband for Rural and Northern Development (BRAND); and

WHEREAS six First Nation service organizations across Canada, including: - Atlantic Canada First Nations Helpdesk (Sydney, Nova Scotia)

- The First Nations Education Council (CEPN-FNEC, Wendake, Quebec)

- Keewaytinook Okimakanak (K-Net, Balmertown, Ontario)

- Keewatin Tribal Council (Thompson, Manitoba)

- Keewatin Career Development Corporation (KCDC, La Ronge, Sask)

- First Nations Education Steering Committee (FNESC, Vancouver, BC) are working together as Regional Management Organizations (RMOs) under contract with Industry Canada's First Nations SchoolNet program to support the development and introduction of ICTs in First Nation schools across Canada; and

WHEREAS establishing a broadband connection at the local First Nation education center will then support each First Nation to use other technologies locally such as wireless, cable or DSL to provide connections to all the other organizations and homes in each community; and

WHEREAS making these services either another public or private service for the community 
requires the ongoing financial support of Indian and Northern Affairs Canada to include these costs within their O\&M funding for education, social services, administration, etc.

THEREFORE BE IT RESOLVED that the Chiefs in Assembly direct our National Chief and the AFN administration to work with Industry Canada and existing programs to develop a strategy that supports every interested First Nation to have access to broadband infrastructure and the required Information and Communication Technologies (ICTs); and

FURTHER BE IT RESOLVED that the Chiefs in Assembly direct our National Chief and the AFN administration to work with Indian and Northem Affairs Canada to ensure the ongoing operation and maintenance (O\&M) of these local resources are adequately sustained in each participating First Nation; and

FINALLY BE IT RESOLVED that the existing First Nation service organizations working with Industry Canada be supported to continue developing and delivering these broadband connections, information technologies and appropriate First Nation applications in partnership with First Nation schools. 